\title{
Abnormal and cytoplasmic connection of guard cells of stomata of leafs of six species of the monocots
}

\author{
Babak Delnavaz Hashemloian, Azra Ataei Azimi* \\ Associate professor of plant cell and developmental biology, Department of Biology, Saveh Branch, Islamic Azad University, Saveh, Iran
}

Email address:

attaei@iau-saveh.ac.ir (A. A. Azimi),delnavas@iau-saveh.ac.ir (B. D. Hashemloian)

To cite this article:

Babak Delnavaz Hashemloian, Azra Ataei Azimi. Abnormal and Cytoplasmic Connection of Guard Cells of Stomata of Leafs of Six Species of the Monocots. Journal of Plant Sciences. Vol. 2, No. 6, 2014, pp. 334-338. doi: 10.11648/j.jps.20140206.21

\begin{abstract}
The present investigation describes abnormal stomata and cytoplasmic connections between guard cells of neighboring stomata in mature leafs of six species of the monocots. The study is made on leaves of Amaryllis reticulate L. Her. Narcissus pseudonarcissus L., Iris langport Wern., Crocus sativus L., Ixiolirion tataricum (Pall.) and Allium cepa L. anomocytic stomata type was observed in all species. Several stomata abnormally include single guard cells, aborted guard cells arrested developments and cytoplasmic connection between guard cells of neighboring stomata was common to all species except in Allium cepa wasn't observed cytoplasmic connection.
\end{abstract}

Keywords: Narcissus, Iris, Crocus, Ixiolirion, Allium, Cytoplasmic connection

\section{Introduction}

Stomata are composed of a pair of guard cells that located on the abaxial and adaxial sides of plant leaves [1]. The stomata of Bougainvillea spectabilis were anomocytic on abnormal leaf. The guard cells were kidney-shaped on normal and abnormal leaf [2]. The stomata were observed in the seeds, primary root, leaf and other parts of plants $[3,4]$. Stomata play an important role in plant innate immunity [5]. Some researchers seek the possible track of plant genetic variation according to studying leaf epidermal stomatal morphology [6,7]. In addition, leaf epidermis stomatal morphology has significance in taxonomy [8]. The stomatal complex of coconut is characterized by the presence of two guard cells and four subsidiary cells, two of which are roundish and the other two are lateral side to the guard cells [9]. Abnormal stomatal patterning or "stomatal cluster" as it is known, has been reported successively in certain species of the family Begoniaceae (Begonia cavaleriei L.), Crassulaceae (Sedum lineare and S. aizoon), Sonneratiaceae (Sonneratia alba J. Smith), and Moraceae (Some species of Ficus) [10]. This distribution is quite different from the normal stomatal patterns [11]. Such stomatal clusters were reported in more than 60 species in the family Gymnosperm, Dicots, and Monocots [12]. Two types of stomatal clusters have found among plants: type A clusters have 2 (or more) stomata placed in direct contact (without intervening epidermal cells between neighboring guard cells), such as: Alysicarpus procumbens Schindl from Papilionaceae [13], Sonneratiaceae, Ginkgo biloba [14] and Annonaceae [15]. While type B clusters are formed by groups of stomata that do not contact with each other (they are separated by the subsidiary cells). Those plants are Crassulaceae (S. lineare) [16], Himantandra parvifolia Bak [17]. These two types of clusters are still not well classified: the term "stomatal cluster" has been used for both types in many studies [18]. Therefore, a clear definition and classification must be redrawn.

Foliar epidermis of nineteen species of Amaryllidaceae, has been studied. Various types of stomatal abnormalitiesviz contiguous stomata, interstomatal cytoplasmic connections etc., are observed in the different species [19]. Leaves of some plants contain normal stomatal patterning and the two types of clusters. Theses used the classical methods which were developed to assess stomatal distribution in ecological studies [20] to evaluate the difference between these two stomatal cluster types.

\section{Materials and Methods}

Isolation of leaf epidermal layers in the present study, stomatal complex was studied by peeling method of leaves. Mature leaves were used to study the dermal characters according to the methods suggested for orchids by Williams [21]. The epiderm peels were obtained from mature leaves of 
Amaryllis reticulate L. Her., Narcissus pseudonarcissus L., Iris langport Wern., Crocus sativus L., Ixiolirion tataricum (Pall.) and Allium cepa L. Eepidermal peels were stained by $0.1 \%$ aqueous metylen blue, $0.1 \%$, aqueous nutrient red, $0.1 \%$ aqueous rodamine and $1 \%$ aqueous safranin for about 3-5 min and munted in $5 \%$ glycerine. A portion of each macerated cuticle was taken for microscopic studies. Observations were made on the microscope to determine stomatal complex types and normality and obnormality stomatal frequency include neighbors' stomata, stomata without guard cells, cytoplasmic connection stomata, un- connection stomata degenerated guard cells frequency. determination of frequency of stomatal complex types using 10 fields of view at $10 \mathrm{X}$ and $40 \mathrm{X}$ objective as a quadrate, the number of subsidiary cells per stoma was noted to determine the types of stomatal complex present in each specimen. Frequency of each stomatal complex type was expressed as \% occurrence of each stomatal complex type based on occurrences of stomatal complex types [22,23]. The slides were observed in Trinocular microscope and photographs were taken. Results were common for all used staining methods.

\section{Results and Discussion}

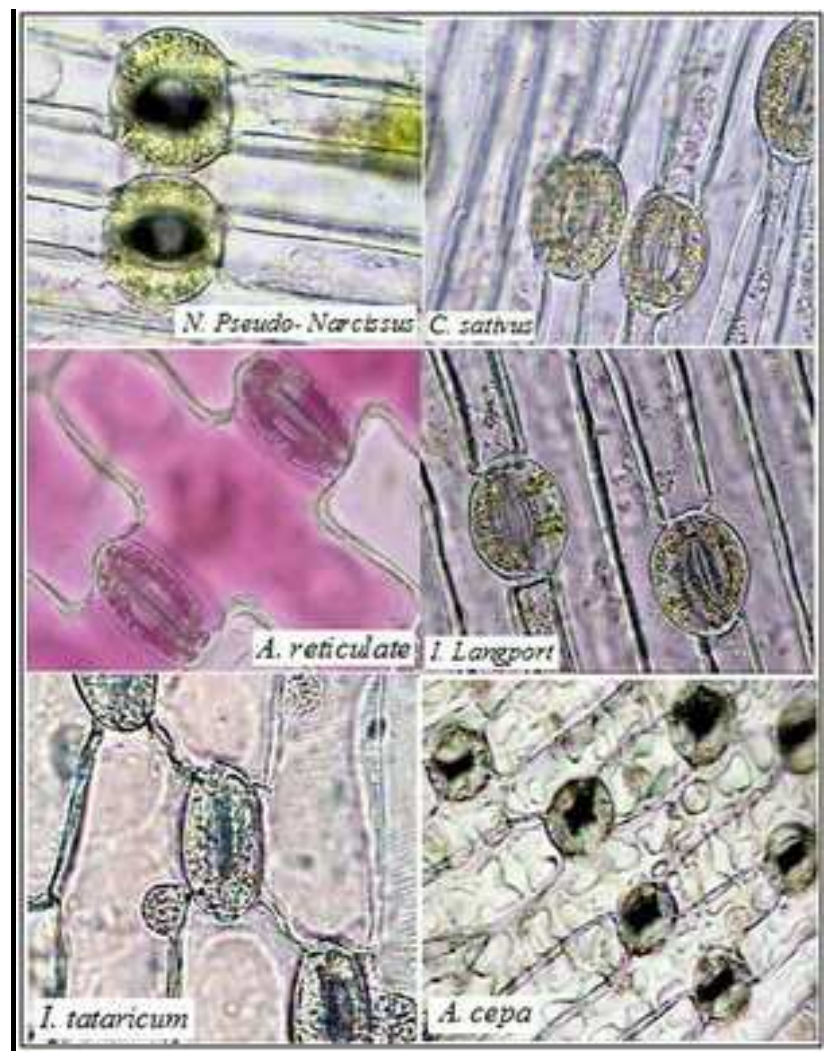

Figure 1. The stomata of all species were anomocytic type and Epidermal cell walls were straight in N. pseudonarcissus, I. langport, C. sativus, I. tataricum and A. cepa, Only in A. reticulate was cross shape.

The stomata of all species were anomocytic type (Figs 1), and their characteristics are shown in Table 1. Epidermal cell walls were observed to be straight in all species (Fig 1), Only in $A$. reticulate was cross shape (Fig 1). Three major types of stomata such as paracytic, tetracytic and anomocytic type present in monocotyledonous plants [24]. Orchidaceae is one of the largest families among monocots. Epidermis studies of orchids showed anomocytic or paracytic stomata are very frequent [25]. The stomata foliar epidermises of nineteen species of Amaryllidaceae were anomocytic. Various types of stomatal abnormality contiguous stomata, interstomatal cytoplasmic connections etc., were observed in the different species [19].

In all species stomata abnormally was observed (Tab 1). Several stomata abnormally were include single guard cells in relationship with normal stomata, aborted guard cells, arrested developments and cytoplasmic connection between nearby stomata or between stomata and epidermal cells. The normale stomata of Narcissus pseudonarcissus L., was the lowest $(61 \%)$ but in Iris langport Wern. was the highest $(98.5 \%)$.

Table 1. Percent of normal and some abnormally characters of stomata of $N$. pseudonarcissus, I. langport, C. sativus, I. tataricum and A. cepa, and A. reticulate

\begin{tabular}{llllllll}
\hline plant & \%ns & \%obs & \%nes & \%ccs & \%ucs & \%dgs & \%swgc \\
\hline $\begin{array}{l}\text { A. reticulate } \\
\text { N. pseudo }\end{array}$ & 86 & 14 & 45 & 8 & 37 & 5 & 1 \\
narcissus & 61 & 39 & 30 & 22 & 8 & 15 & 2 \\
I. langport & 98.5 & 1.5 & 10 & 1 & 9 & 0 & 0.5 \\
C. sativus & 91 & 9 & 14 & 8 & 6 & 0 & 1 \\
I. tataricum & 91 & 9 & 41 & 1 & 40 & 5 & 3 \\
A. cepa & 91 & 9 & 29 & 0 & 29 & 6 & 3 \\
\hline
\end{tabular}

ns: normal stomata, obs: obnormal stomata, nes: neighbors stomata, ccs: cytoplasmic connection stomata. \%ucs: un connection stomata, \%d gs: degenerated guard cells of stomata, \%swgc: stomata without guard cells.

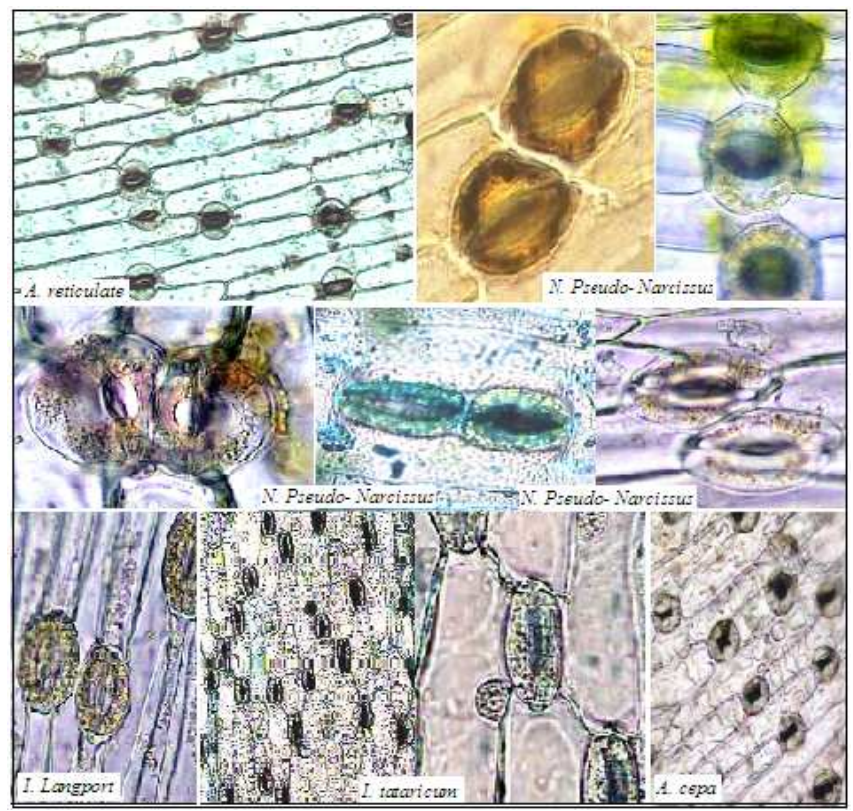

Figure 2. Stomatal clustering in A. reticulate and I. tataricum, in I. langport, A. cepa and N. pseudonarcissus.

Stomata clustering and poly contiguous stomata clustering were observed in the leaf epidermis of $A$. reticulate and I. tataricum, two contiguous stomata in I. langport, 
laterally poly juxtaposed contiguous stomata clustering in the leaf epidermis of $A$. серa and laterally two and three contiguous stomata in N. pseudonarcissus 1. (Fig 2). Stomatal clustering," an abnormal stomatal patterning that is formed by two or more stomata in the leaf epidermis, has been reported in more than 60 species of terrestrial plants [26].

2- The stomata abnormalities include the stomata with one or two single guard cells were observed in $N$. pseudonarcissus and the degenerated guard cells in $A$. reticulate and $N$. pseudonarcissus (Fig.3). In the first type, either one of the guard cells was transformed into a large thin-walled cell or the two neighboring cells by arrested developments. In the latter case the stomata pore is flanked by a single guard cell on one side and two ordinary epidermal cells on the other. The second type is caused by the one or two guard cells heteromorphy by cells degenerated and crushed. Seven types of aberrant and five types of normal stomata of the seedlings of 21 species of Solanaceae are reported. Anomalous stomata were include single guard cell with or without pore; cytoplasmic connection between nearby stomata suggesting their physiological relation; aborted guard cells; and arrested development[27]. The stomatal abnormalities like juxtaposed contiguous stomata and cytoplasmic strands were observed in Asparagus flagellaris and Asparagus africanus respectively. The juxtaposed contiguous stomatal abnormalities were between 3 guard cells while the strand was between 2, 3,4,5,6 stomata [28].

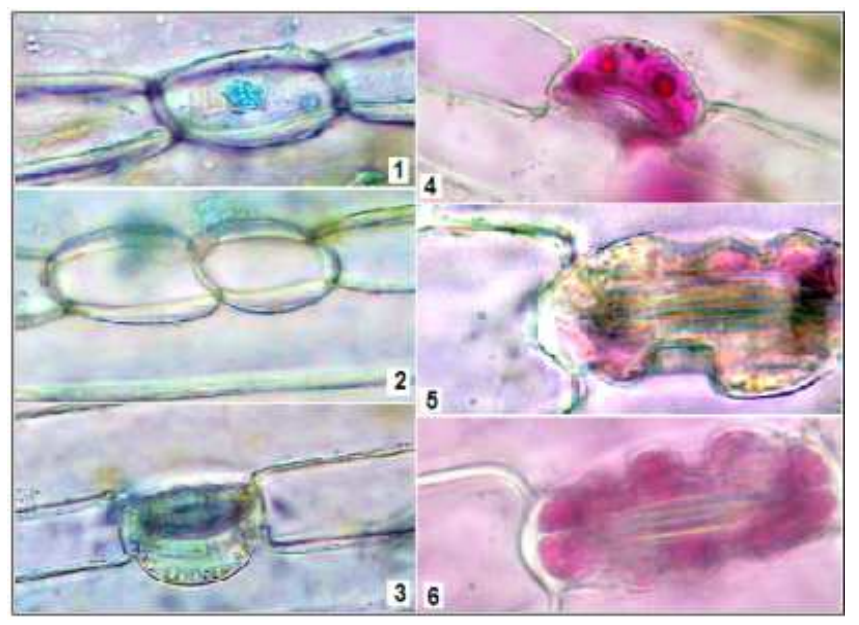

Figure 3. The stomata abnormalities: 1,2,3-one or two single guard cells in N. pseudonarcissusand 4,5,6- the degenerated stomata in A. reticulate, $N$. pseudonarcissus

3- Cytoplasmic strands and connection were observed in all species except $A$. серa. The highest cytoplasmic strands between guard cells were observed in $N$. pseudonarcissus (22\%), A. reticulate $(8 \%)$ and C. sativus $(8 \%)$ respectively (Tab. 1 and Fig. 4). Cytoplasmic connection were absolved between 2, 3, 4, 5 and 6 neighboring stomata of $N$. pseudonarcissus, A. reticulate (Fig. 4).

Cytoplasmic connection between nearby stomata was the a protuberance arises from one of the guard cells of a nearby stomata(Fig. 4:3, 4, 5). The protuberances grow more and more, ultimately meeting and fusing in the center, their fusion wall disintegrated, and a communication channel is formed between two nearby stomata (Fig. 5). This tubular c on nection appears like a conjugation tube between two algal filaments. These guard cells have a cytoplasmic connection which is secondarily developed. The cytoplasmic connection between nearby placed stomata and s o metimes between one of the guard cells and an epidermal cell we re also observed. This indicates that there is some physiological connection between the nearby stomata and guard cell and an epidermal cell. Dahnel observed that they were connected to the relationship of environment and gene structure [29], while Gopal and Shah suggested that contiguous stomatal abnormality are produced due to budding [30].

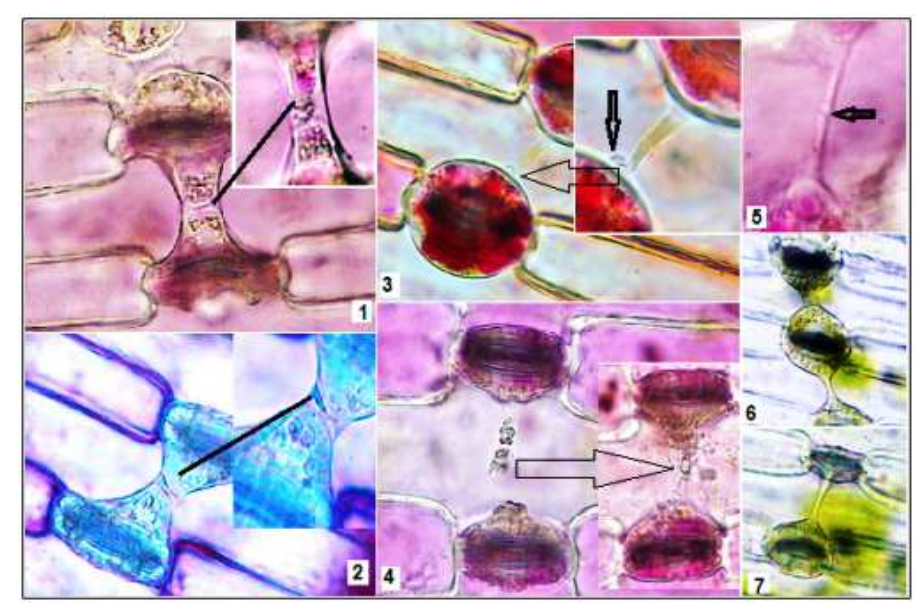

Figure 4. Cytoplasmic strand between two stomata in, A. reticulate $(1,3,4)$, N. pseudonarcissus $(2,5,6,7)$.

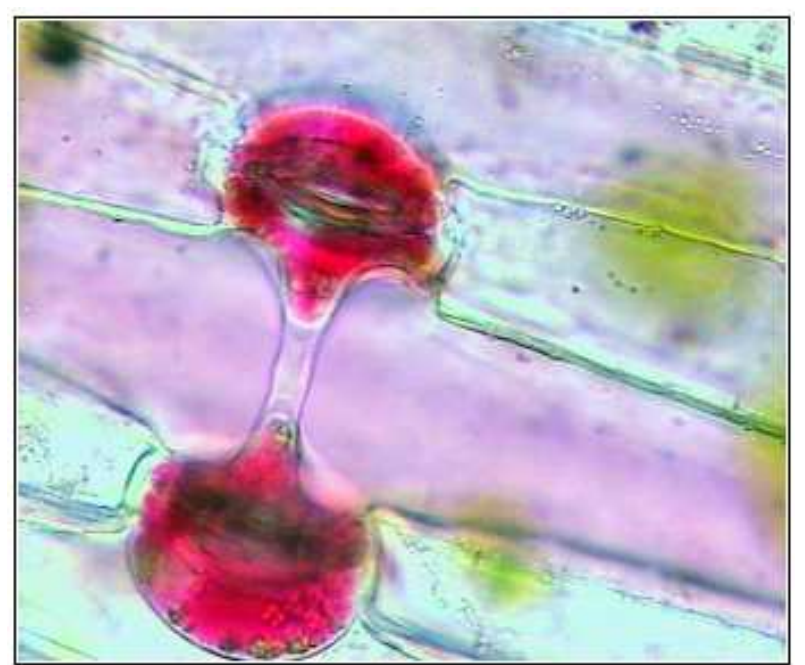

Figure 5. Cytoplasmic strand between two guard cells of two neighboring stomata of $N$. pseudonarcissus

4- Division of guard cell(s) were observed in leafs of Crocus sativus L. (Fig. 6). The guard cells were arised by equal division due to mitosis of the guard mother cells. Anomocytic stomata were arised directly from the 
meristemoid by a straight division and without cutting off any subsidiary cells. At its origin and in early stages of growth, the leaf primordium consists of an undifferentiated mass of contiguous cells without intercellular spaces. The homogeneous mass of cells is organized into layers that soon differentiate and acquire specialized functions. Since plant cells are locked into position by their walls, differentiation takes place without cell movement. However, cells do undergo enlargement particular to their identity and effectively move away from neighbouring cells. The distribution of Crocus sativus stomatal initials on the abaxial blade surface is irregular, but mature stomata are regularly ordered because some initials cease to develop (Fig. 6). Approximately $17 \%$ of undifferentiated epidermal cells become stomatal initials and about $3 \%$ of the initials arrest early in development. Arrest of developing stomata is a common phenomenon in monocots (wheat, corn, Acorus, Brocchinia, Setcreasea, Chlorophytum, Croxdale) [31].

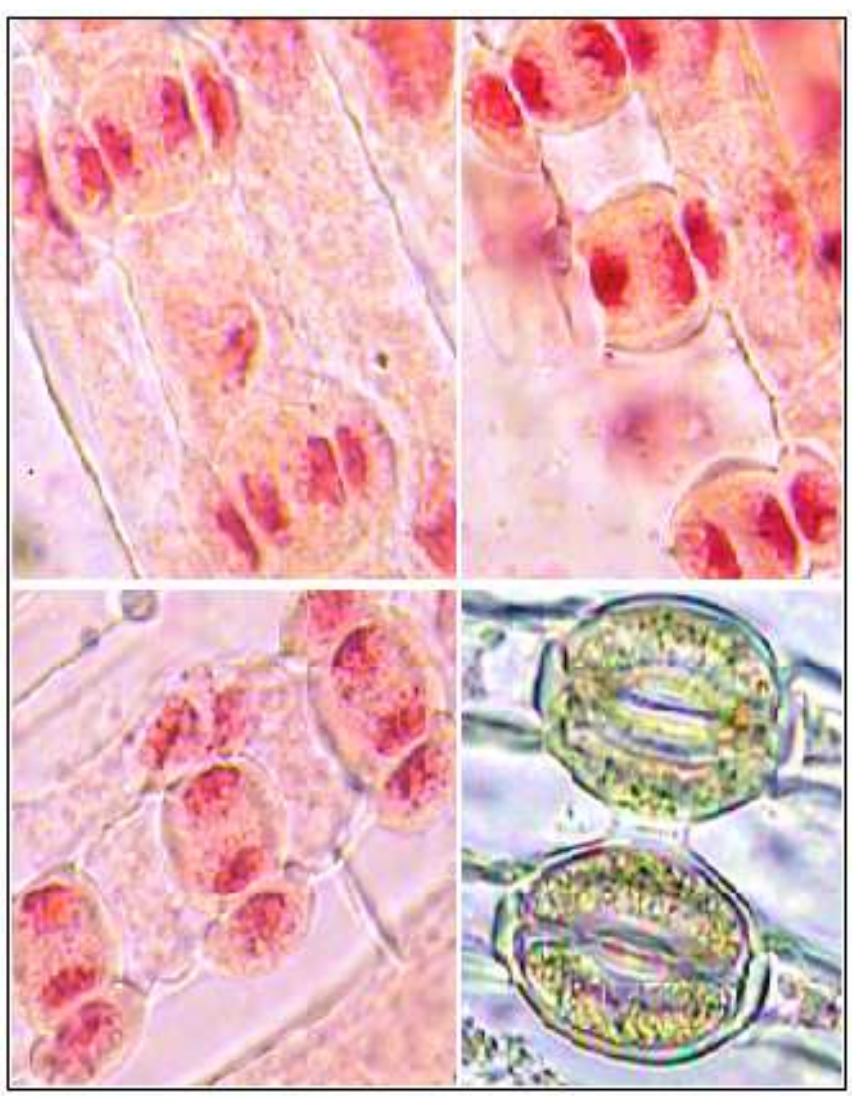

Figure 6. Division of guard cell(s) of leafs of Crocus sativus L.

\section{Conclusion}

The stomata of all species include Amaryllis reticulate L. Her., Narcissus pseudonarcissus L., Iris langport Wern., Crocus sativus L., Ixiolirion tataricum (Pall.) and Allium сера L. were anomocytic type. In all species stomata abnormally was observed. Several stomata abnormally were include single guard cells in relationship with normal stomata, aborted guard cells, arrested developments and cytoplasmic connection between nearby stomata or between stomata and epidermal cells. Stomata clustering and poly contiguous stomata clustering were observed in the leaf epidermis of $A$. reticulate and $I$. tataricum, two contiguous stomata in $I$. langport, laterally poly juxtaposed contiguous stomata clustering in the leaf epidermis of $A$. cepa and laterally two and three contiguous stomata in $N$. pseudonarcissus. Cytoplasmic strands function as translocation channels, and this therefore shows that the guard cells are not physiologically isolated from other epidermal cells. Cytoplasmic strands and connection was observed between guard cells of mature leafs of $N$. pseudonarcissus, A. reticulate, C. sativus, I. tataricum and I. langport.

\section{References}

[1] Hetherington, A.M., Woodward, F.I. 2003. The role of stomata in sensing and driving environmental change. Nature. 424: 901-908.

[2] Croxdale, J.L. 2000. Stomatal patterning in angiosperms. Am. J. Bot. 87: 1069-1080.

[3] Paiva, E.A., Lemos-Filho, J.P., Oliveira, D.M. 2006. Imbition of Swietenia macrophylla (Meliaceae) seeds: The role of stomata. Ann. Bot. 98: 213-217.

[4] Christodoulakis, N.S., Menti, J., Galatis, B. 2002. Structure and development of stomata on the primary root of Ceratonia siliqua L. Ann. Bot. 89: 23-29.

[5] Melotto, M., Underwood, W., Koczan, J., Nomura, K., He, S.Y. 2006. Plant stomata function in innate immunity against bacterial invasion. Cell 126: 969-980.

[6] Li, X.H., Pan, C., Yin, L.J., Shao, J.W., Zhang X.P. 2005. Study on the leaf epidermis of an endangered species, Kirengeshoma palmate, and its related plant. J. Anhui normal. University (Natural Science). 28: 229-332.

[7] Lu, J.H., Li, X.Y., Zhou, L.L., Wu, L. 2005. Characters of leaf epidermis and their systematic significance in Glycyrrhiza. Plant Div. and Reso. (ABY) 27: 525-533.

[8] Wang, Y.G., Li, G.Z., Zhang, W.J., You, J.C., Jia, K. 2007. Leaf epidermal features of Rhododendron (Ericaceae) from China and their systematic significance. Acta Phytotaxon. Sin. 45: 1-20.

[9] Solagi, A. H., Arain, M. A. and Iqbal, M.Z. 2010. Stomatal study of coconut (Cocos nucifera L.), Pak. J. Bot. 42(5): 30153021.

[10] Tang, M., Y.X. Hu, J.X. Lin, and X.B. Jin. 2002. Developmental mechanism and distribution pattern of stomatal clusters in Begonia peltatifolia. Acta Bot. Sin. 44: 384-390.

[11] Pandey, R., Chacko, P.M., Choudhary, M.L., Prasad, K.V. 2007. Higher than optimum temperature under $\mathrm{CO} 2$ enrichment influences stomata anatomical characters in rose (Rosa hybrida). Sci. Hort. 113: 74-81.

[12] Metcalfe, C.R. and Chalk, L..1939. edited by Metcalfe, C. R. et al. 1979. Anatomy of Dicotyledons, Vol. 1 (2nd edition) Clarendon Press, Oxford, 523. 
[13] Nilamoni, B. and Parukutty B. 1979. Contiguous stomata in Desmodium Desv. (Papilionaceae). Current Sci. 48: 27-28.

[14] Chen, L.Q. and Li, C.S. 2004. The epidermal characters and stomatal development of Ginkgo biloba. Bull. Bot. Res. 24: 417-422.

[15] Sun, T.X., Zhao, S. and Zhuang, X.Y. 2001. Leaf epidermal structure in 10 species of Annonaceae. J. Trop. Subt. Bot. 9: 194-200.

[16] Zheng, Y. and Gong, J. 1999. A leaf epidermis study on tweleve species of sedum in AnHui. Bull. Bot. Res. 19: 292297.

[17] Baranova, M. 1972. Systematic anatomy of the leaf epidermis in the Magnoliaceae and some related families. Taxon 21: 447-469.

[18] Zhao, X.Z., Yang, Y.S. and Shen, Z.X. 2006. Stomatal clustering in Cinnamomum camphora. South Africa. J. Bot. 72: 565-569.

[19] Awasthi, D.K., Kumar, V. and Rawat, R. 1984. Stomatal studies in Amaryllidaceae with special reference to stomatal abnormalities, Plant Sci. 93(6): 629-633.

[20] Ndukwu, B.C. and Agbagwa, I.O. 2006. The value of leaf micromorphological in the taxonomic delimitation of Emilia cass. (Asteraceae) species Global. J. Pure Appl. Sci. 1: 183187.

[21] Rasmussen, H. 1981. Terminology and classification of stomata and stomatal development- a critical survey. Bot. J. Linnean Soc. 83: 199-212.

[22] Thuiller, W. .2007. Biodiversity: Climate change and the ecologist. Nature 448(2): 550-552.
[23] van-Cotthem, W.R.J. 1970. A classification of stomatal types. Bot. J.Linnean Soc. 63: 235-246.

[24] Abid, R., Sharmeen, S. and Parveen, A. 2007. Stomatal type of monocots within the Flora of Karachi, Pakistan. Pak. J. Bot, 39(1): 15-21.

[25] Prashantha Kumar, H.G. and Krishnaswamy, K. 2011. A study of Phenology and Stomatal complex of certain epiphytic orchids of Western Ghats of Karnataka, India, RRBB, 2(4):2129.

[26] Gan, Y., Zhou, L., Shen, Z. J., Shen, Z. X., Zhang, Y.Q. and Wang, G. X. 2010. Stomatal clustering, a new marker for environmental perception and adaptation in terrestrial plants. Bot. Stud. 51: 325-336.

[27] Inamdar J. A. and Patel R.C. 1976. Ontogeny of Normal and Abnormal Stomata in Seedlings of Some Solanaceae, Phyton ,17(3,4): 265-276.

[28] Abubakar, B. Y., Tmustapha, O. and Iortsuun, D.N. 2011. Variability of Epidermal Structure and Stomatal Ontogeny in some Species of Asparagaceae from Falgore Game Reserve, New Clues in Sciences 1: 80-83

[29] Dahnel, G.S. 1961. Abnormal stomatal development in foliage leaves of Begonia aradicaulis. Am. J. Bot. 48(2): 129-133.

[30] Gopal, B.V. and Raza, S.H. 1992. Stomatal structures as an aid to the taxonomy of Liliaceae. Asian J. Plant Sci. 4(2): 51-56.

[31] Kagan ML, Sachs T. 1991. Development of immature stomata: evidence for epigenetic selection of a spacing pattern. Dev. Bio. 146, 100-5. 